\title{
Corporate Social Responsibility Accountability through Hamka's Tasawuf Lens
}

\section{Dhina Mustika Sari}

Universitas Mulawarman, Jalan Kuaro, Gunung Kelua, Samarinda 75119, Kalimantan Timur, Indonesia

dhina.mustika.sari@feb.unmul.ac.id

ARTICLE INFO

Article history

Received 6 July 2021

Revised 1 August 202

Accepted 11 August 2021

Keywords

Accountability;

Akhalaqi;

Corporate Social Responsibility;

Hamka's Tasawuf;

Tawhid.

\begin{abstract}
Each entity has the responsibility to contribute in developing the community through a Corporate Social Responsibility (CSR) program. However, the implementation of CSR in modern accounting practices does not always emphasize philanthropy value, instead it still hinges on a capitalistic orientation to maximize profit. The aim of this article is to deconstruct the concept of CSR accountability, which has so far been controlled by capitalistic values. Hamka's Tasawuf thought with the core of tawhid was employed as methodology, which was then complemented by self-awareness as a servant, and refers to an ideology in which one believes that integration of nature, life, and human. This can become the rationale for the construction of social responsibility. Akhlaqy concept on accountability involves religiosity and self-sincerity in implementing CSR. This way, CSR accountability can be directed towards God, as the Giver of Life.
\end{abstract}

This is an open access article under the CC-BY-SA license

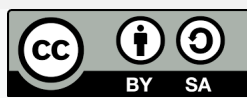

\section{Introduction}

Corporate Social Responsibility (CSR) can be defined as a form of entity's responsibility for its operational activities to the parties involved and those around it. In general, the social responsibility of an entity is divided into accountability for economic, environmental and social aspects or in the term it is also known as the triple bottom line (3P) principle, people, planet, and profit [1]. The CSR program implemented by the entity is interpreted as a concrete manifestation of the concept of sustainability accounting, where this concept focuses on disclosing information on non-financial performance. This concept rests on a value in which the company contributes in economic, environmental and social terms so it is necessary to implement policies that have a sustainable positive impact on these three things. Company policies related to sustainability accounting are then implemented in CSR programs, which include aspects of health, education, environment, and so on, all can be found in the $3 \mathrm{P}$ principles. The implementation of the CSR program has a positive impact on the performance of the company both in terms of financial performance and performance in activities in the capital market as indicated by an increase in stock prices and transaction volume [2-4]. 
CSR itself is in fact more visible in the entity's efforts to "beautify" its appearance rather than sincerely feeling really responsible for the operational activities that have been carried out. The main objective of implementing CSR appears to be merely fulfilling regulatory obligations and maintaining the company's reputation, especially in the eyes of investors and owners of capital. The implementation of CSR as a form of social responsibility does not really able to touch the hearts of business people, and is close to capitalistic thinking. Economic greed still controls the majority of the entity's policies even for policies that are supposed to be philanthropic. The implementation of the CSR program is infused with the interests of homo economicus from holders of economic power. Petrenko et al., (2016) stated that the motivation for CEO narcissism is even higher than the motivation to improve company performance through CSR implementation. This shows the high level of "self interest" both in terms of the entity as a unit and from interested parties, such as CEOs and owners of capital. The 3P principle also clearly reflects the capitalistic interests in it, in which profit is embedded as a principle, which in fact, cannot be separated from efforts to carry out social responsibility. Why does profit still appear in principles that should have been understood purely in generosity? This of course cannot be separated from the ingrained capitalist principles in modern accounting practices derived from capitalist theories. This shows high level of "self interest" both in terms of the entity as a unit and from interested parties, such as CEOs and owners of capital.

In the social context, CSR is seen as an embodiment of social justice, but in modern accounting practice, CSR is reflected as a form of corporate concern for the community and the environment around it. Through CSR, the company is said to have realized the principle of social justice for external parties, in this case specifically for the community and the surrounding environment. However, in reality, there are still many conflicts between the community and companies because of the gaps and injustices in the implementation of corporate social responsibility. The tendency of companies not to really implement social responsibility is found because basically the majority of companies implement CSR only in an obligatory context (Dewi, 2010). The loss of the existence of God and heart in managing a business that is eroded by capitalism and the deification of wealth has changed the world business into a reality that is full of values of greed and skepticism. The kind of justice is embodied by the implementation of CSR seems to be directed towards the pockets of the wealthy 'mafia'. Modern accounting practices have negated God in such a way, even in the sphere of social responsibility where philanthropic values and its inseparability from religions should have existed. The social justice that should be manifested in the implementation of CSR is in fact unable to achieve this principle. The gap in the principle of secularism in modern accounting practices then reduces the values of religiosity from a principle of justice. The principle of justice can be fulfilled when the entity realizes its existence as a part of God's creature that should carry out social responsibility because the conscience calls to take responsibility for what has been done and fulfill it as a form of purification of the wealth it has.

Buya Hamka was a scholar who was very popular with his thoughts on the philosophy of life of modern monotheism and Tasawuf. Hamka's thoughts revolves around social justice. Hamka emphasized that property is a tool and not a goal, where the real goal is to 
remember Allah, to be pleased with Allah, and uphold the way of Allah [7]. This article's aim is to deconstruct the pragmatic CSR accountability, which is only intended for the interests of the entity as a business unit and owner of capital. The CSR needs to return to religious accountability, possess philanthropic values, and involve a sense of justice based on self-awareness as a creature of God. Hamka's Tasawuf thought which discusses social justice, especially in wealth management (and strategy) can be a holistic concept, involving the world and the spiritual in its portion and balance.

\section{Method}

This article aims to return the concept of accountability from CSR to its spirit, where in reality CSR, which is a form of social responsibility, is not implemented according to the social values it should have. The orientation towards profit has mastered the sanctity of the value of an accountability, which is actually intended to be purely philanthropic. This article seeks to construct CSR accountability with the thought of Hamka's tasawuf so that the values of social responsibility in CSR can be implemented in the proper path. This research begins by examining the definition of CSR and conceptual responsibility, which is then followed by a practical review. The conceptual review was carried out by exploring literature study on the initial concept of social responsibility. Reviewing this concept was carried out by investigating the main originators of the concept of social responsibility, namely Carroll (1979), which divides social responsibility into 4 (four) aspects. Furthermore, a review was carried out on the founder of the triple bottom line concept as the principle underlying the implementation of CSR, namely Elkington (1998). In the next stage, theory that underlies the triple bottom line concept was traced. A review was then carried out on the theory of legitimacy and the theory of stakeholders which are the fundamental theories of accountability. Further, a review of CSR is carried out in the concept of deep and shallow ecology to illustrate the reality of the accountability of CSR implementation. Finally, a conceptual discussion regarding efforts to restore accountability to its proper values, which is viewed from 2 (two) Tasawuf thoughts, namely Hamka Tasawuf and Ali Yafie's Tasawuf. In the end the article emphasizes CSR accountability in Hamka's Tasawuf concept.

\section{Results and Discussions}

\subsection{The History of Corporate Social Responsibility}

CSR as an embodiment of the concept of sustainable accounting is generally outlined in sustainability reports and in stand-alone reports. CSR is defined as a form of social responsibility that is realized in social programs such as in the aspects of human resources, education, health, economic development, conservation and environmental care, as well as other aspects. Social responsibility itself basically appeared in $1700 \mathrm{BC}$, which was written in the Code of Hammurabi, where there were 282 (two hundred and eighty-two) laws governing the imposition of sanctions for entrepreneurs who provide poor and substandard services and cause the death of their customers. In the 1930s, the world recession was quite large and it resulted in a high number of companies that went bankrupt, further resulting in an increase in the number of unemployed. However, most companies at the time did not 
care about the condition of their workers, and consequently causing waves of anger. Faced with this dissatisfaction, some companies then took steps of moral responsibility in the form of providing guarantees for employees who were taken out of their jobs. The term CSR is not yet known at this time, but efforts to carry out moral responsibility have emerged. In the 1940s, the term community development (comdev) began to be known and used in England in 1948, where this term replaced the term mass education that was commonly used before. There are several alternatives in relation to this approach, namely the community approach, the problem-solving approach, the experimental approach, the power conflict approach, natural resource management, and the improvement of the urban community environment. The most common approach at that time was the community approach because it involved high participation from the community and parties related to planning, implementing, and evaluating the implementation of comdev activities.

In the 1950s, Bowen gave an initial definition of CSR, namely as a policy set to carry out operational activities by involving the values prevailing in society. Bowen is referred to as The Father of Corporate Social Responsibility because he formulates the concept of social responsibility as an obligation to realize a policy and make a decision by considering the goals and values that apply in society. The concept of social responsibility in this era shows the continuation of the implementation of various charity activities and as a form of human care that was practiced quite a lot by business people in the early 1900s to the 1930s. There are 3 (three) points of view related to the explanation of social responsibility, trusteeship, balancing of interests, and services. In this era, stewardship theory is the basis for implementing CSR because of the stewardship principle that managers consider in making decisions. In this concept, Friedman argues that social responsibility includes how the company runs its organization to achieve profit maximization, according to the wishes of the owners of capital. Simultaneously, the company also considers the basic norms and rules that apply in a community [10].

In the 1960s to 1970s the concept of social responsibility in CSR was influenced by stakeholder management. Stanford Research Institute (SRI) researchers introduced the concept of stakeholders according to Freeman and Raid in 1963 which initially referred to the definition of "those groups without whose support the organization would cease to exist" [11]. Stakeholders in Freeman's perception are individuals or groups who influence each other in relation to company goals. The consideration of the existence of these stakeholders can influence efforts to achieve corporate goals effectively. The dimension of corporate responsibility is transformed from economic responsibility for capital owners (shareholders) through profit maximization to responsibility to the wider community (stakeholders). In era 1980's to nowadays, the CSR concept developed based on Carroll's notion about social responsibilities whom divide it in four elements, namely economic responsibility, legal responsibility, ethical responsibility and discretionary responsibility [8]. Economic responsibility, emphasizing social responsibility related to economic responsibility in relation to as a profit-oriented business entity. Legal responsibilities, this social responsibility emphasizes the responsibility of business organizations in the legal aspect, where the law is made in its role as a regulation that is essentially made by the community through the legislative body. Ethical responsibility, in this case social responsibility, emphasizes the expectations of the community so that business 
organizations can carry out their operations ethically, where ethics reflects moral values. Discretionary responsibilities is also often referred to as citizenship responsibilities. This social responsibility refers to the community's expectation that the company will provide benefits for them. This responsibility also relates to the company's tendency to maintain its reputation in the eyes of society as part of a good citizen. The development of the CSR concept is also influenced by the disciplines of business ethics, corporate governance, and sustainable development. The concept of CSR has recently evolved towards corporate social performance, which underlies CSR implementation. Based on this concept, the goal of CSR is based on the dimensions of financial performance, where the purpose of making voluntary charity is not the only reason for implementing CSR but is also based on company expectations to increase the impact of CSR implementation on corporate financial performance.

In Indonesia itself, the term CSR became known in the 1980s and was increasingly popularly implemented in the 1990s. CSR activities in Indonesia are basically carried out in the form of social assistance even though the term CSR is not clearly used in this assistance. This assistance includes natural disaster assistance, educational scholarships, holiday allowances, and several other similar assistance. In 2003, the Ministry of Social Affairs as a government agency actively advocated and developed the concept of CSR for companies in Indonesia. Pressure from non-governmental organizations (NGOs) that are concerned with environmental issues, labor, and women has also become part of the birth of CSR in Indonesia. A number of laws and regulations, including sectoral ones, have regulated the implementation of CSR. Several regulations on CSR programs have started to emerge in Indonesia along with the passing of Law Number 40 of 2007 concerning Limited Liability Companies and Law Number 25 of 2007 concerning Investment. Generally CSR disclosure is voluntary in nature, however in Indonesia CSR disclosure is mandatory for companies engaged in natural resource management. Several regulations have supported the implementation of CSR even to the level of local government regulations.

In terms of its history, CSR was originally based on the social dimension of the human conscience so as not to harm others and to be responsible for the business activities carried out. The development of modern knowledge that negates the subjectivity and values of religiosity also has an impact on the perspective and orientation of human life. Likewise in the aspect of social responsibility, where this domain is directed at efforts to maximize profits to increase the prosperity of the owners of capital. The development of western CSR has certainly hurt the religious philanthropic value of CSR, where CSR should be a form of social accountability for a business organization carried out with sincere intentions and in the principle of social justice. CSR implementation should depart from the mandated human obligation to regulate nature in the context of devotion to God [12]. The development of modern accounting through modern accounting theories has also invaded the concept of social responsibility and has increasingly dominated and blinded the eyes of business people by closing the conscience and religious spirit in implementing a sense of responsibility. The concept of triple bottom line (or 3P) is the principle that underlies sustainability accounting and CSR implementation, where this concept is basically also 
born in modern knowledge thinking that only rests on logical reasoning but detaches itself from religiosity.

\subsection{Accountability Corporate Social Responsibility - For Whom?}

Talking about the accountability of CSR, with all the capitalist concepts that remain attached then raises a question, then actually to whom is the accountability of this CSR aimed at? When viewed from the definition of CSR in general, social responsibility is actually aimed at parties that are relevant to the company's business activities, including community groups, employees, the environment, government and other interested parties. Judging from the early history of the development of CSR, basically social responsibility is prioritized as a form of moral responsibility of a business organization to those who support its business and are affected by its business activities. Social responsibility is carried out purely as a soul calling to be responsible for the negative impacts caused. Until here, humanist values are still attached to the existing concept of social responsibility. However, along with the development of modernization which also diffuses into the development of accounting practices, these humanist values are ignored because modernity rejects subjectivity and everything that is related to conscience, especially religious values.

Carroll (1979) even divides the dimensions of social responsibility with an unequal division. Economic responsibilities occupy the largest portion to be "considered" in implementing social responsibility. For the next aspect, a regressive portion is given in which the discretionary responsibilities have the smallest portion to be considered. Even so, in discretionary responsibilities, which this aspect includes the community's expectation of benefits that will be received in return for the impact that is felt, in reality it is carried out to maintain reputation and avoid conflicts with communities that have the potential to occur and can interfere with the sustainability of their business. Based on CSR trends and practices, Social responsibility as a business component shows that CSR can be sustainable only if it has an impact on increasing the value of the company's success continuously which can be measured through material performance and popularity among investors [13]. Schwartz \& Carroll (2003) then revised the social responsibility component by changing the term discretionary responsibility to philanthropic responsibilities. Basically, the component division is still carried out in regressive proportions from the base of the pyramid. The notion of CSR remains business-centered, which implies that economic responsibility takes precedence over other responsibilities. Corporate philanthropic is even still based on economic motives that are oriented towards long-term business sustainability, even the economic aspect is the basis of the overall foundation of social responsibility. This is also evident and clearly presented in the Sustainability Report (SR) of the Indonesian Stock Exchange issuers, which clearly states that its main orientation is profit achievement, as presented in the SR of one of the leading SOEs as follows:

“... To realize sustainability, in running its business the Company always adheres to the triple bottom line, namely seeking profit in doing business by paying attention to social concerns (people) and environmental preservation (planet). By implementing this concept, the Company is committed to building harmony and 
balance between the three. In an effort to gain profit, the Company will carefully analyze the various opportunities that exist and formulate the best strategy to achieve the business targets that have been set...."

It is very clear that the priority of implementing sustainability accounting is profit. Social care activities carried out are adjusted to profit orientation, which means that if the activity is not profitable, it will not be implemented. This orientation is a materialistic orientation in modern accounting concepts, which is basically done to increase the prosperity of the owners of capital, because profit is basically intended for increasing the coffers of the superior group's wealth. This reality has torn the value of pure philanthropy and justice from a social responsibility.

Referring to eco-centrism, where eco-centrism is a theory of environmental ethics that focuses ethics on the entire ecological community, whether living or not, so that moral obligations and responsibilities apply to all ecological realities and are not limited to living things. Deep ecology as a version of the theory of eco-centrism demands a new ethic that is centered on all living things and not only on humans, this is done as an effort to overcome environmental problems. Deep ecology recognizes the intrinsic values of all living things and views humans as only a special part of the web of life. Anthropocentrism ethics has alienated humans from their essence as ecological creatures who realize that their life is dependent on other humans and the environment around them, causing an environmental crisis. Anthropocentrism has led humans to destructive and exploitative behavior patterns. Anthropocentricism is part of shallow ecology [15], namely the view that humans are above or outside nature, and humans are also separate from nature, which is contrary to deep ecological view, where humans are not separate from nature. Shallow ecology emphasizes that the environment is used for the benefit of humans [16]. Although there is concern for the sustainability of nature and the environment, this is done solely for the benefit of humans.

The practice of social responsibility through the implementation of CSR, which has been carried out by public companies, appears to be of more shallow ecological value than deep ecology. Profit-oriented CSR accountability then ignores the values of true concern for the community and the environment around it. CSR activities that are programmed are only activities that are carried out as a "sweetener" for the company, especially for external parties. CSR implementation is like a social tool used for materiality purposes of a business organization. CSR accountability is still aimed to the owners of capital, with a profit orientation that provides benefits for the owners of capital. CSR implementation is also carried out with the expectation of a return from the community to be able to provide "comfort" for the sustainability of the company's business.

\subsection{Triple Bottom Line in Modern Accounting Theories: Negating Religiosity}

The UN has set Sustainable Development Goals (SDGs) to be fully achieved and realized in 2030, which aims to protect the environment, reduce social inequality, and reduce poverty. This global action involves several countries in the world including Indonesia through the determination of 17 (seventeen) goals and 169 (one hundred sixty nine) targets as outlined in the SDGs. In this regard, business organizations are also asked 
to be actively involved in this action through the implementation of the concept of sustainability accounting which is imbued with the concept of sustainable development. In sustainability accounting, the responsibility of business organizations shifts from a single bottom line, namely the financial dimension to the triple bottom line which includes economic, social, and environmental elements or better known as profit, people, and planet. The triple bottom line was initiated by Elkington (1998), a sustainability consultant who serves advocacy services for the integration of CSR activities in company business activities, who argues that future market success will depend heavily on the company's ability to fulfill three components, namely profitability, environmental quality, and social justice. Elkington then simplifies this term as profit, people, planet or the popular acronym 3P. Profit is determined as the basis for every business activity achieved through increased productivity and cost efficiency, so that this becomes an economic responsibility that must be fulfilled. People refers to society as part of stakeholders, where the company is responsible for this group because of the need for support from the community to maintain the principle of going concern and the progress of its business activities. This is also done because the awareness of the community will have an impact on the good reputation of the company. Planet refers to the environment, where every operational activity carried out by the company considers environmental preservation with the aim of creating a healthy and comfortable environment and maintaining the availability of resources, which in turn will also have an impact on business continuity. The $3 \mathrm{P}$ concept then becomes a principle in sustainability accounting that underlies CSR implementation.

It is argued that the triple bottom line concept is a meaningless concept [17]. The 3P concept became so popular and spread very quickly among multinational companies and then the majority of companies used the 3P integration services provided by CSR and sustainability consultants. Basically, a company that implements its social responsibility in CSR should be based on the traditional values that exist within the organization itself, and without the 3P concept, this responsibility can be carried out [17]. The Pentaple Bottom Line idea in modifying the triple bottom line principle by adding aspects of phenotechnology and prophets was then proposed (Sukoharsono, 2019). Aspects of people, profit, and planets are defined the same as those defined in the 3P principle, adding that the achievement of profit needs to be balanced with other aspects of $P$. Phenotechnology refers to a fact in which the phenomenon of information technology is increasingly developing at this time and becomes a vital part of organizational management. In this concept, the use of technology used in the company, whether in the form of software, hardware, databases and other relevant things, needs to be disclosed. Meanwhile, prophet refers to spiritual and mental balance in the preservation of life, where companies need to express Godconsciousness, transcendental awareness, honesty, self-contemplation ability, and sincerity.

In practice, the triple bottom line cannot be separated from the principle of social responsibility which is implemented in CSR practices. Social responsibility in CSR is like a product offered to stakeholders, so it still uses materialistic calculations of the costs incurred. Marom (2006: 196) presents a mathematical formulation of the calculation of CSR profit in 2 equations, namely The CSR-related profits equal rewards and The total firm reward, as follows [11]: 
Profit $\mathrm{CSR}=\mathrm{R}-\mathrm{C}=\mathrm{UTs} \times \mathrm{S}-\mathrm{C}$

CSR Profit $=\sum \mathrm{Rij}-\sum \mathrm{Cj}$

Where,

$\mathrm{R}=$ Total reward

$\mathrm{C}=\mathrm{CSR}$ cost

$\mathrm{U}=$ Utility function from certain stakeholder groups (T) for each social output (S)

$\mathrm{S} \quad=$ Social output

This equation clearly explains that social responsibility is carried out by taking into account the utility of the social activities carried out on the profit to be achieved. Profit here can be in the form of a good reputation from the company which will then have an impact on increasing investor interest which in the end is done to achieve prosperity only for the owners of capital.

In relative terms, profit is not a forbidden thing to consider, but it should not always be the life of company policy even for a sense of care and empathy. The triple bottom line principle that is influenced by modern accounting materiality is derived from the theory of legitimacy and stakeholder theory, which is a product of capitalist thinking. CSR as an implementation of social responsibility is carried out based on the principle of the triple bottom line, which is an accounting practice derived from theories that are seminally derived from capitalistic theories. Legitimacy theory and stakeholder theory are theories that generally underlie this social responsibility practice. Fundamentally, legitimacy states what should happen and why something can happen. Legitimacy theory is based on the existence of a social contract between the organization and the community which then becomes the basis for determining company policies in order to achieve a company management process that is congruent with the needs of society [19]. In this case, a company needs to gain legitimacy from the surrounding social environment in order to maintain its business continuity. To be able to reduce the legitimacy gap, companies must identify the activities they can control and also identify public groups that have the power to provide legitimacy to the company, one of which is through disclosure of environmental responsibility [20]. Basically, The ultimate goal of a legitimacy process pursued by a business organization is inseparable from efforts to maximize profit gains, where through this legitimacy the company will get a good reputation which will have an impact on increasing company value. One of the implementation of CSR is applied to gain corporate legitimacy so that it can be accepted in a social sphere, so that the implementation of social responsibility is basically also inseparable from the goal of increasing company value and maximizing profit. This reality proves that legitimacy theory fails to explain the expected social contract in determining policies so as to achieve company management that is in line with community needs.

The concept of stakeholders is developed based on the concept of the company's organizational environment which influences the way managers viewpoints to achieve corporate goals effectively. The purpose of developing the concept of stakeholders is to explain corporate behavior and social performance, where stakeholders are defined as any group or individual that can influence or be influenced by the achievement of company 
goals (Freeman, 1999, p. 46). Stakeholder theory is closely related to legitimacy theory because the fulfillment of the legitimacy of an entity is strongly influenced by stakeholder acceptance of the entity. In this theory, the social responsibility of business organizations is perceived to the extent to which the company pays attention to the interests of stakeholders which are reflected in the decisions made by management. Jones (1995) then classifies stakeholders into 2 (two) groups, namely inside stakeholders, which include shareholders, managers and employees, and outside stakeholders, which include customers, suppliers, government, local communities, and the general public. Stakeholder theory states that the company as an entity not only emphasizes the interests of the company but also implements the principle of benefit to stakeholders, which include government, local communities, and the general public. Stakeholder theory states that the company as an entity not only emphasizes the interests of the company but also implements the principle of benefit to stakeholders.

CSR implementation is also inseparable from this stakeholder theory because it is related to legitimacy. CSR activities with a stakeholder theory approach are to ensure that the company is socially responsible for all company stakeholders (Yusuf, 2017: 39). It is in line with what is derived from the legitimacy theory that the company needs to maintain its good relationship with stakeholders. The accommodation of the wants and needs of stakeholders in this theory needs to be done and prioritizes the needs of stakeholders who have power over the availability of resources. In CSR implementation, the emphasis on implementation through the establishment of policies does not fulfill the principle of justice, where the needs of internal stakeholders, in this case, the owners of capital are prioritized and provided in a larger portion. The estuary of this consideration is of course a return to profit, which will increase the prosperity of the owners of capital. The same failure is also shown by stakeholder theory in explaining the concept of social responsibility in companies. This theory is proven to only side with stakeholders who have power and resources, while marginal groups will only be considered when it has an impact on profit achievement.

Genetically, legitimacy theory and stakeholder theory are derived from modern accounting perspectives and practices that tend to be capitalistic and secular, where these theories develop from the concept of entity theory. The concept of Entity Theory focuses on the economic unit, where the center "serving" is no longer the owner but shifts to the business unit [23]. Entity theory emerged as a result of the development of the capital market era and Multi National Companies and is the result of the evolution of proprietary theory, which is the theory that animates accounting. This theory appears in the basic substance of the company's objectives, types of capital, the meaning of accounts, and other things, which are all viewed from the perspective of the owner and emphasizes the interests of the owners, especially in terms of certainty and analysis of their net assets [23]. These theories are rooted in modernist thought, which focuses on the growth of materiality and its measurement. The neglect of subjectivity and religiosity makes these theories form a secular accounting practice, which favors only those who have the resources. The social responsibility derived from these theories is only a form of product and a tool used as a shield to cover the soul of greed in business management. These theories clearly show to 
whom this alignment is addressed and what kind of justice is realized from a social accountability.

\subsection{The Concept of Accountability in Ali Yafie's Tasawuf Thought}

CSR accountability has been strongly influenced by modern accounting values that embrace anthropocentric values where these values encourage people to materialistic behavior. CSR implementation as a form of social responsibility should be done purely as a form of human responsibility for what has been done to the community and the environment around it. Returning the concept of CSR accountability to its purity can be done using the thoughts of Tasawuf thinkers. Tasawuf is the science of knowing how to purify the soul, clear morals, build dhahir and mind and to obtain eternal happiness. Prof. $\mathrm{KH}$ Ali Yafie is one of the Muslim intellectuals whose thoughts are quite prominent, where to be able to manage themselves, caring for the heart and arranging the mind well, it is necessary to recognize 3 (three) basic concepts of life, namely lust, reason, and heart [24]. Lust functions as a source of driving, reason as a power of thought, power of reason, as well as control, and heart is a component that is very close to religion. In reality, the heart is the component that plays the least part in modern society today. According to Ali Yafie, the scope of Tasawuf lies in the recognition of the human self, especially the mind so that humans have the characteristics of cleanliness, simplicity, and devotion. Returning gratitude, according to Ali Yafie, is one way of being grateful. at the same time controlling, and the heart is a component that is very close to religion. In reality, the heart is the component that plays the least part in modern society today.

Basically, this Tasawuf thought can be applied in shaping the concept of CSR accountability, because CSR programs can be treated as a form of reciprocation. However, if viewed from social responsibility in a more specific way, this idea does not yet provide a concept that is more appropriate to CSR accountability. The components of life based on Ali Yafie's thoughts, namely, passion, reason, and an integrated heart are basically able to become the soul of CSR implementation but have not holistically touched the form of social responsibility. The life component has not been able to explain further the concept of social responsibility accountability, which will only come to an explanation on the surface. The principle of reciprocation can still be analogous to the value of self-interest in carrying out social responsibility.

\subsection{Accountability with the Concept of Akhlaqy in Hamka's Modern Tasawuf Thought}

One of Indonesia's outstanding intellectuals Prof. Dr. H. Abdul Malik Karim Amrullah (HAMKA) or known as Buya Hamka is an Indonesian scholar and thinker with a variety of thoughts that are quite critical of the realities of life in Indonesia. One of Hamka's wellknown thoughts is Hamka's Modern Tasawuf which places monotheism as a fundamental part of all philosophy of life. Tasawuf is an effort to develop humans in terms of words, deeds, and hearts, by making a relationship to Allah SWT as the basis for action, both in a small scope as a wider scope of person [25]. Humans as social beings, carried by the currents of modernism, then become pragmatic and materialistic, This is what happened in the development of modern accounting which was controlled by the concept of capitalist 
economics. Buya Hamka himself has criticized the development of the capitalist economy, by initiating a human revolution in which humans must return to their awareness of themselves as God's creatures and place God in every thought and action of change. In Buya Hamka's view, there are 3 (three) ideological principles which are essentially one, consisting the maujud of nature, life, and human beings who have transcended the triple bottom line concept in social responsibility initiated by Elkington [26]. This concept then becomes a more specific concept and is suitable for social responsibility. In Hamka's thought, God is the only way to get away from the shackles of domination of modernity which is very widespread. The value of justice that should have been reflected in the implementation of CSR was then torn apart by capitalistic powers so that the value of social justice that should have been absent. The return to thinking about the concept of accountability to God is a way out of this injustice.

The concept of akhlaqy as a style of Hamka's Tasawuf emphasizes efforts to perfect and purify the soul, which is manifested in a well-ordered mental attitude and disciplined behavior. This concept is in line with efforts to restore CSR accountability as a form of social responsibility on the right track. Social responsibility is actually implemented in 2 (two) main concepts, namely transcendental responsibility and purification of property. In the context of responsibility to God, CSR accountability should be directed religiously not to humans, but to God, because nature and all its contents are not human creations but the creation of the Almighty. What has been done and utilized from God's creation should be accounted for by His creator through the sanctity of philanthropic actions which are carried out purely because of the values of habluminallah and the actions of habluminannas which are sincere and selfless. The reflection of injustice in the implementation of CSR cannot be separated from the arrogance of human attitudes, where the arrogance of the rulers has damaged the basis of social justice. Absolute justice, which is not partial to its scales, is not affected by sentiments of feelings of love and hate, justice does not change because of kinship and familial, and is not influenced by fellow ideologies or contradicts [7]. A social responsibility for the use of resources is not a tool, rather the wealth and resources are a tool and not an end. Purification of the purpose of all aspects of life, including the management of business organizations, returns to remembering Allah, towards Allah's approval, and enforcing the way of Allah. Accountability should depart from the understanding that property does not belong to humans but is Maal Ullah or belongs to God, humans as caliphs on earth only have the duty to be representatives to maintain these assets. The concept of representative here differs from the concept of representative in stewardship, which underlies social responsibility in modern accounting. In the context of business organization, existing assets and resources do not belong to the company or even do not belong to the community, but belong to Allah, which must be regulated in such a way that the community and the company each get what is truly their right; towards the Ridho (blessing) from Allah, and enforcing the way of Allah.

Hamka explained that the concept of purifying property is related to human awareness that in every property owned, there are rights of others, which keep away from the element of greed. The struggle in fostering and building in an organization uses 2 (two) conditions, namely property (amwal) and self (anfus) [7]. The earth has been sufficient to meet human needs, but in fact humans use it by using reason, not desire, so that humans are allowed to 
use resources as assets but with self-awareness through their intellect and conscience. This self-awareness will lead to equitable utilization of resources, fair for nature and just for the community and entitled parties. Accountability with the concept of morality is built to be able to construct the concept of social responsibility, in which accountability is centered on monotheism which then with the awareness of the concept of habluminallah and habluminannas sincerely gives the rights of employees, the community, the environment, and other parties who are purified from the tendency to maintain reputation, popularity, and maximize profit. CSR implementation is carried out with the principle of social justice which rests on 3 (three) main Hamka ideologies, namely maujud of nature, life and human beings. Tawhid will be the core of all actions, which is then manifested in ideology and a rationale that understands the nature of nature, the nature of life, and the nature of human beings who emerge then underlie the emergence of accountable actions. This action is based on transcendental awareness and the nature of purification of assets, which is manifested in the implementation of CSR. Accounting in the concept of akhlaqy returns social responsibility accounting to God as the owner of life and the entire universe so that the implementation of social responsibility through CSR is not based on legitimate or economic motives. This concept will bring the essence of CSR to social justice, which is pure philanthropic value because it is based on a religious awareness.

\section{Conclusion}

Social responsibility has become a very popular issue in the last few decades. However, the concept of social responsibility has basically emerged centuries ago, where social responsibility at that time was more directed towards moral responsibility through charitable activities. Along with the development of modern accounting, the concept of social responsibility appears in the context of CSR which is based on the principles of corporate financial performance, in which the CSR program implemented is adjusted and measured how its impact on the company's financial performance, in this case profit achievement. The concept of social responsibility in the mastery of modern accounting is also inseparable from measurement, especially the measurement of how big the impact of CSR is on acceptable profits. This reality shows that the values of social purity that should be the soul of CSR implementation are damaged by the modern accounting capitalistic motive which is oriented towards maximizing profit to increase the prosperity of capital owners and other groups in power. CSR in modern accounting is based on the triple bottom line principle which consists of the aspects of profit, people and planet (3P). This $3 \mathrm{P}$ principle clearly states that social responsibility does not escape everything that will have an impact on profit, even the profit aspect is a dimension that underlies the construction of social responsibility. In fact, this was clearly conveyed in the Sustainability Report of one of the BUMNs in Indonesia.

Buya Hamka's Tasawuf thought, which underlies all actions on the value of monotheism and then guides humans to awareness of their identity as a servant of God becomes the basis for the construction of religious social responsibility. It is different from Ali Yafie's Tasawuf principle, which is more appropriate if it is applied to self-Tasawuf because it has not specifically touched the value of social responsibility. Based on Hamka's Tasawuf thought, the triple bottom line concept in modern accounting is substituted by the 
principle of social justice, which is based on 3 (three) ideologies, namely the nature of nature, the nature of life, and the nature of human beings who appear. Through the concept of akhlaqy, social responsibility is built into 2 (two) main concepts, namely transcendental responsibility and purification of property. Transcendental responsibility includes the awareness of responsibility to God who has provided the earth and all its contents to be managed by humans in the best possible and fairest way. The concept of purification of property refers to the concept that property does not belong to humans but belongs to God which is entrusted to humans where in the property there is a need for purification by surrendering another person's share of the total property owned. Accountability in the thought of Hamka's Tasawuf involves religious values and philanthropic values in the concept of social responsibility. In this concept, social responsibility comes from monotheism, which is then implemented based on 3 (three) ideological principles, namely nature, life and human beings. These values place social responsibility accountability at the essence that it should be, namely to God so that implementing CSR is not based solely on the profit motive.

\section{References:}

[1] Elkington J. Enter the Triple Bottom Line 2001;1:1-16.

[2] Balabanis G, Phillips HC, Lyall J. Corporate social responsibility and economic performance in the top British companies: Are they linked? Eur Bus Rev 1998;98:25-44. doi:10.1108/09555349810195529.

[3] Mustafa SA, Othman AR, Perumal S. Corporate Social Responsibility and Company Performance in the Malaysian Context. Procedia - Soc Behav Sci 2012;65:897-905. doi:10.1016/j.sbspro.2012.11.217.

[4] Zamil GMS, Hassan Z. Impact of Environmental Reporting on Financial Performance: Study of Global Fortune 500 Companies. Indones J Sustain Account Manag 2019;3:109. doi:10.28992/ijsam.v3i2.78.

[5] Petrenko O V., Aime F, Ridge J, Hill A. Corporate social responsibility or CEO narcissism? CSR motivations and organizational performance. Strateg Manag J 2016;37:262-79. doi:10.1002/smj.2348.

[6] Gusti I, Agung A, Dewi O. Dialektika Dan Refleksi Kritis Realitas "Sustainability" Dalam Praktik Sustainability Reporting: Sebuah Narasi Habermasian. J Akunt Keuang Indones 2010;7:139-52.

[7] Hamka. Keadilan Sosial-hamka. Jakarta: Gema Insani; 2015.

[8] Carroll AB. A Three-Dimensional Conceptual Model of Corporate Performance. vol. 4. 1979.

[9] Elkington J. Partnerships from Cannibals with Forks: The Triple Bottom line of 21 st Century Business. Environ Qual Manag 1998;Autumn:37-51.

[10] Baron DP, Friedman M. Corporate Social Responsibility and Social Entrepreneurship. J Econ Manag Strateg 2007;16:683-717.

[11] Kartini D. Corporate Social Responsibillity, Transformasi Konsep Sustainability Management dan Implementasi di Indonesia. Bandung: Refika Aditama; 2020.

[12] Yusuf MY. Islamic Corporate Social Responsibility (I-CSR) pada Lembaga Keuangan Syariah (LKS), Teori dan Praktik. Depok: Kencana; 2017.

[13] Carroll AB. A History of Corporate Social Responsibility: Concepts and Practices. Oxford Handb. Corp. Soc. Responsib., Oxford University Press; 2009. doi:10.1093/oxfordhb/9780199211593.003.0002. 
[14] Schwartz MS, Carroll AB. Corporate Social Responsibility: A Three-Domain Approach. Bus Ethics Q 2003;13:503-30.

[15] Capra F. The Web of Life A New Scientific Understanding of Living Systems 1997. New York: An Anchor Book; 1997.

[16] Capra F. Deep Ecology: Educational Possibilities for the Twenty-First Century. NAMTA J 2013;38:201-16.

[17] Norman W, Macdonald C. Getting to the Bottom of "Triple Bottom Line." vol. 14. 2004.

[18] Ganis Sukoharsono E. Sustaining A Sustainability Report By Modifying Triple Bottom Line To Pentaple Bottom Line: An Imaginary Research Dialogue. vol. 119. 2019.

[19] Dowling J, Pfeffer J. Pacific Sociological Association Organizational Legitimacy: Social Values and Organizational Behavior. vol. 18. 1975.

[20] Neu D, Warsame H, Pedwell K. Managing Public Impressions: Environmental Disclosures In Annual Reports*. Accounting, Organ Soc 1998;23:265-82.

[21] Freeman RE. Divergent Stakeholder Theory. vol. 24. 1999.

[22] Jones TM. Instrumental Stakeholder Theory: A Synthesis of Ethics and Economics. Acad Manag Fleview 1995;20:404-37.

[23] Mulawarman AD. Nyanyian Metodologi Akuntansi ala Nataatmadja: Melampaui Derridian Mengembangkan Pemikiran Bangsa "Sendiri." J Akunt Multiparadigma 2013;4. doi:10.18202/jamal.2013.04.7189.

[24] Wiwoho B. Bertasawuf di Zaman Edan. Jakarta: Buku Republika; 2019.

[25] Masrur. Pemikiran dan Corak Tasawuf Hamka dalam Tafsir Al-Azhar. J Stud Islam $2016 ; 14$.

[26] Kamayanti A. Metodologi Konstruktif Riset Akuntansi: Membumikan Religiositas. Jakarta: Yayasan Rumah Peneleh; 2017. 
This page is intentionally left blank 